\title{
Perfil bioquímico-hematológico em Ihamas (Lama glama Linnaeus 1758) criadas em cativeiro no Sul do Brasil: variações de gênero e época do ano*
}

\author{
ELISANDRO OLIVEIRA DOS SANTOS
}

André Silva Caríssimi (Orientador - UFRGS)

Félix Hilário Diaz González (Co-Orientador - UFRGS)

Banca: Maria do Carmo Both (UFRGS), Sérgio Ceroni da Silva (UFRGS), Sônia Terezinha dos Anjos Lopes (UFSM).

As lhamas são camelídeos sul-americanos encontrados em criações zoológicas no Brasil, com grande adaptação a diferentes regiões do mundo. Devido às variações que ocorrem em decorrência da influência da região, nutrição e resposta individual dos animais, é importante caracterizar seus parâmetros fisiológicos para estabelecer valores de referência para a espécie. O objetivo do presente trabalho foi estudar valores hematológicos e bioquímicos de lhamas, de um zoológico localizado no município de Gravataí, Rio Grande do Sul, Brasil, avaliando também possíveis diferenças entre sexo e períodos do ano. Os resultados obtidos foram comparados com aqueles descritos na literatura, objetivando contribuir para a compreensão dos mecanismos que afetam sua adaptação na região. Foram utilizadas 16 lhamas clinicamente saudáveis, 8 machos e 8 fêmeas, na faixa etária de 1 a 6 anos de idade. Foram realizadas 8 coletas de sangue para cada sexo através de venipunção jugular, durante o período de um ano. Na comparação entre os sexos, observaram-se diferenças significativas de leucócitos, CK, AST, colesterol, creatinina, frutosamina, glicose, triglicerídeos, albumina, globulinas e fósforo. Em relação a época do ano, houve diferenças significativas para hemoglobina, triglicerídeos, frutosamina, colesterol, creatinina, proteínas plasmáticas totais, albumina, globulinas, glicose, nas enzimas ALT, AST, LDH e CK, e nos níveis de cálcio e fósforo entre alguns meses. Comparando-se os valores encontrados com a literatura, os níveis de triglicerídeos, globulinas, CK, LDH, uréia e fósforo foram elevados, além de magnésio que mostrou-se mais alto nas fêmeas, enquanto os demais metabólitos tiveram valores similares. Os resultados encontrados mostraram as lhamas possuem diferentes maneiras de responderem ao manejo, adaptando-se a situações novas num ambiente em constante transformação. Os valores encontrados podem servir como valores de referência para lhamas criadas no sul do Brasil.

Descritores: lhamas, perfil bioquímico-hematológico, valores de referência, variações sazonais, variações de gênero.

Apresentada: 18 maio 2006

"Dissertação de Mestrado n. 434 (Especialidade: Patologia Animal). 85f. Programa de Pós-graduação em Ciências Veterinárias [www.ufrgs.br/ ppgcv], Faculdade de Veterinária, Universidade Federal do Rio Grande do Sul (UFRGS), Porto Alegre, RS/Brasil. CORRESPONDÊNCIA: E.O. Santos [elisandrosantos@ pop.com.br]. 


\title{
Biochemical and hematological profiles in llamas (Lama glama Linnaeus 1758) creation in captivity in the South of Brazil: gender and seasons variations**
}

\author{
ELISANDRO OLIVEIRA DOS SANTOS
}

\author{
André Silva Caríssimi (Orientador - UFRGS)
}

Félix Hilário Diaz González (Co-Orientador - UFRGS)

Committee: Maria do Carmo Both (UFRGS), Sérgio Ceroni da Silva (UFRGS), Sônia Terezinha dos Anjos Lopes (UFSM).

Llamas are south American camelids found in zoological parks from Brazil, and are adaptable in different world conditions. Due the influence of the region (mainly climate and altitude), nutrition and individual animal response, is important to characterize physiological parameters for this establishes reference values and understanding the standard for this species. The objective of this study was to establish reference values for llamas in a zoological on borough Gravataí-RS, by evaluating the biochemical and hematological profiles between sex and different seasons. Sixteen clinically healthy llamas (eight males and eight females), aged one to six years-Old were used in this trial. Eight blood collections were performed for each gender through jugular venipuncture, along one year. In the comparison between gender, significant differences were observed to leukocites, CK, AST, cholesterol, creatinine, fructosamine, glucose, TG, albumin, globulin and P in some months. With respect to the year period, statistical difference was founded in the $\mathrm{Hb}$, TG, fructosamine, cholesterol, creatinine, total protein, albumin, globulin, glucose determinations. Enzymes as ALT, AST, LDH, CK, and Ca and P level showed altered in some months. In comparison with data from literature, the values to the TG, globulin, $\mathrm{CK}, \mathrm{LDH}$, urea and $\mathrm{P}$ were elevated, besides $\mathrm{Mg}$ wich exhibit high in the females. Other metabolic data were similar with literature report. The results demonstrate that animals own different way of the response the husbandry, adaptation for new situations in the environment in constant transformation. On this basis, the results can be useful as reference values for llamas maintained in the south of Brazil.

Key words: llamas, biochemical and hematological profiles, reference values, seasons variations, gender variations.

Presented: 18 May 2006

\footnotetext{
** Master's Thesis \# 434 (Field: Veterinary Pathology). 85p. Graduate Program in Veterinary Sciences [www.ufrgs.br/ppgcv], Faculdade de Veterinária, Universidade Federal do Rio Grande do Sul (UFRGS), Porto Alegre, RS/Brazil. CORRESPONDENCE: E.O. Santos [elisandrosantos@ pop.com.br].
} 